\title{
O ato de escrever entre as paredes
}

Uma história dos quartos.

PERROT, Michelle.

São Paulo: Paz e Terra, 201 1, 344p.

Contos e romances têm sido os alvos dos tinteiros de escritores/as, especialmente nos últimos séculos. Mulheres reclusas em seus lares, em suas obrigações, diversas vezes estereotipadas, crianças escutando histórias - às vezes amedrontadas - médicos/as, trabalhadoras do sexo e tantos outros/as estão representados/as ou se utilizaram da literatura para inscreverem seus sentimentos e suas percepções sobre a experiência que viveram. Dessa forma, a literatura tornou-se mais que um modo de escrita, uma prática, um gesto.

A literatura enquanto fonte é um dos recursos muito utilizados no livro de Michelle Perrot, intitulado Uma História dos quartos e publicado pela Editora Paz e Terra no ano de 2011. A autora tem como um dos seus principais trabalhos a organização da obra História das Mulheres no Ocidente, de cinco volumes, publicados no Brasil entre 1993 e 1995, pela Editora Ebradil, junto ao historiador George Duby. Entrementes, tornou-se reconhecida no Brasil ainda em 1988, quando foi publicado pela Editora Paz e Terra o livro Os excluídos da história: operários, mulheres e prisioneiros. ${ }^{1}$ A perspectiva de uma história social foi o que marcou o início da trajetória da historiadora, a qual hoje é representante mundial da historiografia da história das mulheres.

O livro Uma história dos quartos é dividido em 12 capítulos, e em todos eles a escrita é permeada por noções do filósofo Michel Foucault. Baseada nas ideias desse autor, Michelle Perrot analisa que os lugares são palcos de disputas das relações de poder, envolvendo desde as necessidades da casa até mesmo as decisões geopolíticas. Já no primeiro capítulo a autora apresenta as suas ideias para realizar esse trabalho. Entre ruídos e risadas, pode-se tecer um caminho das práticas culturais de um convento, da residência de uma burguesa, de 
uma operária ou, ainda, dos passos de meninas, carinhosamente chamadas de "filhas" por Simone de Beauvoir, enquanto ela escrevia. A erudição de Perrot possibilita citar desde os romances de Gustave Flaubert e de Virginia Woolf, entre tantos/ as outros/as, até os diários de mulheres, de viajantes, etc. Dos modos de se ler à cama, de compreender as subjetividades nos atos de leitura e de escrita do ambiente sociocultural de cada personagem/indivíduo destacado nesse livro, pode-se chegar a uma análise social do quarto.

$\mathrm{O}$ uso da literatura enquanto fonte situa-se em um tempo em que a história tem revisto a sua metodologia. As discussões vindas a partir dos anos de 1960 questionaram sobre a construção dos fatos, denunciando o essencialismo que a história afirmava ter em relação ao que se passou. O gênero narrativo ganhou espaço novamente, isso porque até o século XVIII os traços literários faziam parte do fazer histórico. Porém, esse entrecruzamento da História e da Literatura deuse de modo diverso do primeiro. No fim do século XX, a credibilidade da filosofia hegeliana da história foi derrubada, isto é, percebeu-se que não há uma só verdade; é preciso pensar na hermenêutica, nas narrações sobre as impressões que são registadas nos discursos dos indivíduos. ${ }^{2}$

Nesse bojo, história e literatura passaram a andar mais juntas, pois compartilham do estado da palavra, ${ }^{3}$ a qual é relacional e cultural. Nessa altura, autores como Hayden White foram amplamente criticados, visto que o autor inutilizou o caráter histórico e de veracidade que a história como ciência vinha buscado, desde o século XVIII. ${ }^{4}$ Apesar das similaridades, pontuo que ambas têm gêneros narrativos diferentes no que concerne às regras da própria escrita, mas se tratam de narrações do tempo, do sujeito e do espaço, utilizando metáforas e linguagens. Desse modo, a história perdeu a "materialidade" do passado, o que permitiu que a literatura retornasse ao leque das fontes historiográficas.

Nesse sentido, Michelle Perrot se utiliza da literatura ricamente para compreender mais sobre o cultural e o social, especialmente da França. Nos capítulos dois e três, nomeados respectivamente de "O Quarto do Rei" e "Quarto de Dormir", a preocupação da autora é apontar o modo como os quartos reais tinham posições estratégicas, exercendo um poder panóptico sobre o palácio. Utilizando romances de Honoré de Balcaz, de Émile Zola, e estudos de Alexis de Tocqueville, Perrot demonstra, nessa parte de seu ensaio, como o quarto foi se constituindo como um locus de descanso, representativo da unidade orgânica da família, da privacidade, na qual a sexualidade era permitida - e talvez somente ali - como um centro de normalidade e dentro dos preceitos higiênicos.

O capítulo seguinte apresenta o quarto como um local de isolamento a partir do século $\mathrm{XV}$, um direito ao segredo (de Kafka, por exemplo). Lembrados também são os diários - tão estudados por Philippe Lejeune - que consomem os segredos, o desconforto de alguns ope-rários assediados por outros, os quartos tão arrumados das mulheres, como se as representassem imaculadas. É notória, ainda, a história da leitura que perpassa as convenções sociais habituais, como bem lembra Perrot, ao citar Alberto Manguel ( $p$. 88). De fato, a autora demonstra como a literatura é aflorada entre os lençóis, e ainda alerta-nos sobre a importância dos diários para as mulheres, justamente por ser considerada uma escrita marginal, um entrelugar (privado e público). Já o capítulo cinco é dedicado às crianças, em especial aos detalhes conquistados nos quartos das pequenas.

O sexto capítulo versa sobre o quarto das mulheres. Nesse, a casa é vista como o lugar das mulheres - especialmente a cozinha - e o quarto como o local da noite de núpcias, dos partos. Nesse sentido, Perrot cita uma frase de Virginia Woolf: "As mulheres ficaram em sua casa durante milhares de anos, por isso hoje as próprias paredes estão impregnadas de sua força criadora" ( $p$. 131). E é nesse teto todo seu que elas solaparam muitos dos limites impostos. São também os quartos das máquinas singers e das prostituições. O quarto é a conquista de um espaço, das leituras às escondidas que permitiam sonhar com alguns dos lugares tão ocupados atualmente por nós, mulheres.

No sétimo capítulo, Quartos de hotel, Perrot percorre desde os albergues de Daniel Roche os quais já hospedavam coletivamente peregrinos, viajantes, até os da péssima rede hoteleira descrita em diários de viagem. Para analisar o oitavo capítulo, é preciso um olhar social, o que é notório em Perrot, haja vista a sua trajetória. Os "Quartos operários" demonstram aspectos que, segundo a historiadora, estão há mais de 200 anos sem solução. Assim, ela utiliza pesquisas, tratados e questionários do Ministério Público para perceber as nuances de operários que se amontoavam em pequenos quartos presenciando incestos, a falta de emprego e os imigrantes ilegais.

O nono capítulo apresenta a escrita de George Sand em seus últimos dias. Por meio das cartas da escritora, Perrot procura demonstrar como se davam os relatos médicos, os cuidados 
sob o corpo, o que cabia às mulheres e aos homens. A sagração da escritora, também analisada por Fillipie Ariés, foi reforçada pela família e pelos amigos. O capítulo dez trata-se dos quartos à prova de som, como o de Emily Dickson, a qual passou a maior parte do seu tempo trancada nele, sem parecer perceber o que ocorria à sua volta, assim como Marcel Proust, para o qual "o silêncio tornava a alma mais sensível "( $p$. 274).

Michelle Perrot encerra seu livro descrevendo o quarto como um lugar de práticas normalizadoras, um terreno de experiências, um local democrático e, por vezes, solitário. Para a autora o quarto ainda mantém seus segredos, mas apresenta a nós, historiadores/as, suas manchas e suas paredes (às vezes com ouvidos). O que Perrot demonstra brilhantemente nesse ensaio é uma nova perspectiva de se pensar o social, o cultural, de perceber a dualidade entre o público e o privado a partir dos quartos descritos pela literatura. Nesta, não é a veracidade dos personagens ou os seus atos que importam, mas as questões colocadas pelos/as escritores/as. A literatura mostra o desconhecido, o esquecido na poeira ou no arquivo.

Embora o livro de Perrot reforce significativamente o olhar literário que devemos ter em nossa própria narrativa historiográfica, evidencia tantos nomes, autores/as e romances que ocasiona uma necessidade de se fazerem outros estudos, a fim de perceber em cada escritor/a nuances para uma história das mulheres, entre tantas outras.

\section{Notas}

I Joana Maria PEDRO, 2003.

2 José Carlos Reis, 2010.

${ }^{3}$ Durval Muniz ALBUQUERQUE JUNIOR, 2011.

${ }^{4}$ Sobre esse assunto, ver Hayden WHITE, 2001.

\section{Referências}

ALBUQUERQUE JUNIOR, Durval Muniz. "Em Estado de Palavra: quando a história não consegue que se meta fora a literatura". In: FLORES, Maria Bernadete Ramos; PIAZZA, Maria de Fátima Fontes (Orgs.). História e Arte: movimentos artísticos e correntes intelectuais. Campinas: Mercado das Letras, 2011 . p. 249 261.

PEDRO, Joana Maria. "Um diálogo sobre mulheres e história". Revista de Estudos Feministas, v. 11 , n. 2, p. 509-212, 2003.

REIS, José Carlos. O desafio historiográfico. São Paulo: FGV, 2010.

WHITE, Hayden. Trópicos do discurso. São Paulo: Edusp, 2001.

Lorena Zomer

Universidade Federal de Santa Catarina 